\title{
ASSESSING LEARNING STYLES OF UNDERGRADUATE LOGISTICS STUDENTS USING KOLB'S LEARNING STYLE INVENTORY: A CROSS-SECTIONAL SURVEY
}

\author{
M. F. Mpwanya* \\ Department of Marketing, Logistics and Sport Management \\ e-mail: francismpwanya@gmail.com / http://orcid.org/0000-0002-8582-2606
}

\section{S. Dockrat ${ }^{*}$}

Directorate for Student Development and Support

e-mail: DockratS@tut.ac.za / http://orcid.org/0000-0002-4812-3443

${ }^{*}$ Tshwane University of Technology

Pretoria, South Africa

\section{ABSTRACT}

Understanding students' learning styles and adapting instructional strategies to the variety of student learning styles are determinants for effective learning and enhance learning performance. Using Kolb's learning style inventory (LSI) and demographic questions, this study assesses the learning styles of undergraduate logistics university students by identifying their dominant learning style and by exploring whether students' demographic factors influence their learning styles. To this end, a cross-sectional survey involving 429 undergraduate logistics university students in South Africa was conducted. The results show that accommodating learning style as the most predominant learning style among undergraduate logistics university students, followed by students with assimilating learning style. The combined proportion of these two groups of students represents more than two-thirds of the sampled population. The study's findings show that gender and learning styles were significantly related. While the majority of male logistics students displayed the diverging learning style, their female counterparts exhibited the converging learning style. On the other hand, learning styles and age group; learning styles and type of high school attended; and learning styles and nationality were found not to be related. This study has implications for practice and extends the literature on learning styles and demographic factors in the unexplored logistics discipline.

Keywords: learning styles, Kolb learning style inventory, cross-section survey, undergraduate logistics students, demographic factors

\section{INTRODUCTION}

From the time of birth, human beings embark on the journey of discovering the world around them through their senses (see, touch, smell, taste and hear) and, thereby, build a body of 
knowledge (Kaur 2014). This body of knowledge increases with formal and informal learning entities, but each human being is wired from birth with abilities to perceive the information in his/her own way (Kaur 2014). One of the questions that has preoccupied the minds of many educators in various disciplines over the years and has resulted in a wave of studies around the world is: "How do individual students learn?"

It has been well documented that students learn in different ways (Shanker 1990; Litzinger and Osif 1993; Budeva, Kehaiova and Petkus 2015). Identifying factors that influence how individual students learn is vital in ensuring effective learning and better learning performance. One of the factors that should be considered is student learning style. Fleming (2001) defines learning style as the way people prefer to collect, organise and process information. Keefe $(1979,4)$ views learning style as cognitive, affective and physiological capabilities that indicate a learner's individual approach in response to the learning situation or environment. According to Mills (2002), learning style is a complex process in which students engage in preserving, recalling and processing ideas in effective and efficient manner in a given learning situation. In this study, learning style refers to cognitive and perceptual abilities by which a learner acquires, organises, processes and assimilates information to respond to a learning task or a situational demand.

Educational scholars posit that learning styles vary from one student to another (Shanker 1990; Litzinger and Osif 1993; Murphy, Gray, Straja and Bogert 2004; Shah, Ahmed, Shenoy and Srikant 2013). This reality constrains educators from various disciplines, including business and management sciences such as logistics, to be aware of their students' learning styles.

\section{Rationale of study and problem statement}

This study focuses on a specific target academic programme, namely Logistics, which is offered at undergraduate level (from National Diploma to Bachelor of Technology). The choice is motivated by the fact that one of the authors of this study specialises in Logistics and lectures Logistics at the Department of Marketing, Logistics and Sport Management. The Department of Higher Education and Training has identified Logistics as one of the scare skills in South Africa (SA 2014). To ensure availability of logistics skills and grow South Africa's economy in alignment with the National Development Plan, education is of utmost importance. Since education is viewed as "the study of how learning takes place" (Fletcher, Potts and Ballinger 2008, 378), assessing learning styles of undergraduate Logistics students and matching these with teaching methods are some of the ways of improving academic performance in institutions of higher learning that offer logistics programme(s) and for the provision of logistics skills needed by the industry. 
The knowledge generated from this study would assist Logistics lecturers in the department to understand their students' learning styles and align their teaching methods accordingly. It should also assist not only the Logistics Section within the Department of Marketing, Logistics and Sport Management, but other sections within departments and faculties to identify student needs per learning mode and learning style and to ensure availability of needed teaching tools and technologies (such as computer lab software for logistics simulations).

Despite more than five decades of student learning styles practice in education (Carol 2015), the increasing number of studies on learning styles of business and management students as well as the increasing need for improved academic performance in institutions of higher learning in both developing and developed countries and the recognition of logistics as a driver for economic growth of nations, no published study investigating how logistics students learn using Kolb's LSI was found in South Africa and globally. In addition, there are no studies that investigate the relationships between learning styles and demographic and academic factors of logistics students using Kolb's LSI. Therefore, the primary objective of this study is to assess learning styles of logistics at a South African institution of higher learning using Kolb's LSI. The secondary objective is to identify the dominant learning style of logistics students at a South African institution of higher learning, using Kolb's LSI, and to explore the relationships between learning styles and demographic factors.

\section{LITERATURE REVIEW}

Vishwakarma, Verma and Mitra $(2015,148)$ state that "students learn in many ways, and teachers differ in instructional methods. Nevertheless, both students and teachers share the same goal to reach optimal learning." One of the ways to achieve optimal learning is through awareness of students' learning styles. Pashler, McDaniel, Rohrer and Bjork (2008) opine that awareness and nurturing of learning styles are driven by the established learner-teacher relationship, because of the involvement of two critical factors: the preference and the ability. Studies on learning styles argue that learning could be used as a key tool for identifying and unlocking learning performance potentiality (Kolb and Kolb 2005; Smith and Ragan 1999; Sun, Lin and $\mathrm{Yu}$ 2008). On the other hand, several studies also provide evidence to suggest that teaching styles aligned with learning styles can enhance student learning performance (Jorgensen 2006; Vita 2001; Lovelace 2005) and attitudes toward learning (Lovelace 2005). This is consistent with Dunn and Dunn (1978), who advocate the use of different learning styles to match distinct student learning preferences during different instructional activities. In support of this view, Ghaffari, Ranjbarzadeh, Azar, Hassanzadeh, Safaei, Golanbar, Mazouchian and Abbasi 
(2013) state that instructional methods that match learning styles will increase student satisfaction with their learning.

In the field of education there are many learning models and measurement instruments for assessing individual learning styles. These include the Learning Style Inventory (LSI) (Kolb 1976), the Learning Style Questionnaire (LSQ) (Honey and Mumford 1982), the Herrmann Brain Dominance Instrument (HBDI) (Herrmann 1989), the Index of Learning Styles (ILS) (Felder and Solomon 1997) and the visual, aural, reading and kinaesthetic (VARK) (Fleming 2001). Nevertheless, in the context of this study, LSI is used since it is "based on a comprehensive theory of learning and development" (Kolb and Kolb 2005, 1).

LSI was developed by David Kolb to test the experiential learning theory and has become one of the preferred learning theories by scholars (Kolb 1984). This theory emphasises experience acquisition translating into ideas that are used by learners to generate or create new experiences. It also views learning as a four-stage cycle comprising two continuums or dimensions: the grasping continuum (indicates how students perceive information) and the internalising continuum (indicates how students process information) (Kolb 1984). These two continuums form an axis of four learning modes divided into quadrants, as illustrated in Figure 1. On the vertical axis, the student perceives experience (information) either through feeling and intuition (concrete experience, CE) or conceptualising an idea or theory (abstract conceptualisation, AC). On the horizontal axis, the student processes experience (information) either through watching and reflection (reflective observation, RO) or doing (active experimentation, AE) (Kolb 1984; 1985). Vertical and horizontal axes of learning styles reflect the four learning styles as described in many studies (Kolb 1984; 1985; Holley and Jenkins 1993; Felder 1996; Kolb and Kolb 2005): accommodating, diverging, converging and assimilating. Accommodating learning style describes individuals who learn through hands-on experiences and intuition rather than logical analysis and enjoy facing new and challenging experiences. Individuals with diverging learning styles prefer to generate ideas in groups through brainstorming and have interests in cultural diversity in order to process information from multiple perspectives. Converging students are best at finding practical applications for built theories in real-life situations. Assimilating learning style emphasises more on ideas than people and use inductive reasoning to generate theory. Individuals with assimilating learning style prefer analysing a wide range of information and summarising and presenting it for decision making. They emphasise logical soundness of theories rather than practical value of theories. 


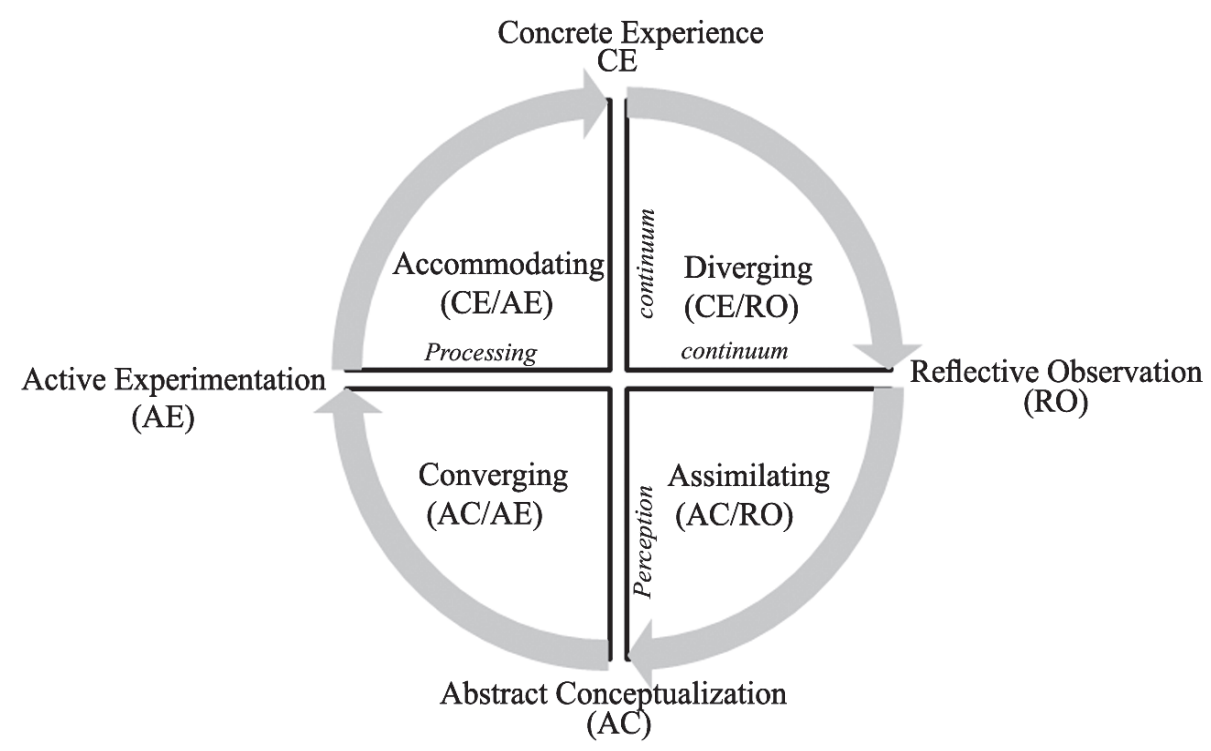

Figure 1: Learning modes and learning styles (Source: Kolb 1985)

Many studies have used LSI to assess learning styles in various disciplines, including business and management sciences. For instance, Gardner and Korth (1998) used LSI to measure the relationships between the four learning styles and graduate students' attitudes toward four learning methods (such as lecture, paper writing and pair learning) and students' attitudes toward teamwork. The study found that assimilating students preferred to attend lectures and writing papers, while accommodating students showed a preference for teamwork. Terrell (2002) compared students' graduation rate by learning styles. He found that most of students showed or exhibited either the converging learning style or assimilating learning style. Akkoyunlu and Soylu (2008) investigated students' perceptions in a blended learning environment in relation to their learning styles. The study found large differences between student learning styles and their perceptions on the blended learning process, such as easy use of online learning tools, assessment and traditional classroom environment setting. Blended learning is defined as a new learning system in education that combines face-to-face lectures (traditional education) with online learning courses (e-learning) (Voos 2003; Garrison and Kanuka 2004; Graham 2006; Macdonald 2008).

Goorha and Mohan (2009) examined the relationships between learning preferences, teaching strategies and course content in a business school. The findings indicated that business students were converging and assimilating learners. Ghaffari et al. (2013), in their study on the 
relationship between learning styles and academic achievement of medical students, found that students' academic performance and their learning styles were not significantly associated. However, assimilating and converging learning style were dominant. Budeva, Kehaiova and Petkus (2015) compared the learning styles from two samples of undergraduate marketing students from the United States of America and Bulgaria. The results suggest that students from the two countries displayed different learning styles, with most of students preferring the assimilating and converging styles. However, only one out of four learning styles mode differs in the two samples.

Education literature links learning styles and demographic characteristics such as age, gender and culture as a learner engages in the learning process (Boström 2012; Bosman and Schulze 2018). This connection has been supported by several empirical studies. For instance, Kiwanuka, Van Damme, Van den Noortgate, Anumenden and Namusisi (2015) report that mathematics performance of first-year high school students in Central Uganda differed based on their gender. Gender was, therefore, found to be a significant predictor of mathematics achievement, while age was not. Female students underperformed significantly in mathematics achievement in comparison to male students. Cho (2016) examines the relationship between learning styles and teaching styles in a mathematics class at a South African metropolitan university. He found that male students were independent (of their lecturers' guidance when learning) in mathematics class and female students tended to be dependent on the lecturers, although the majority of lecturers disagreed with this finding. From a perceiving and receiving information standpoint, the findings of the same study showed that male students exhibited visual and intuitive learning preferences, while female students tended to be sensing and verbal learners.

Wehrwein, Lujan and DiCarlo (2007) investigated the association between gender differences and learning style preferences among medical undergraduate students. The findings reported demonstrated that most of the males exhibited a multimodal learning style, while most of their female counterparts were unimodal. This finding, however, does not correlate with that of a similar study conducted by Slater, Lujan and DiCarlo (2007), which showed that gender and learning styles did not differ significantly. In addition, it was observed that while both genders (males and females) exhibited multimodal learning style preferences, the female students were greatly diverse (10 of the 11 options) within multimodal preferences, while their male counterparts associated with a smaller subgroup or subunit (6 of the 11 options) of multimodal preferences.

Dlodlo, Mvelase and Krause $(2010,13)$ used a case study strategy to investigate the relationship between learning styles, gender and Information and Communication Technology 
(ICT) career choices at the Council for Scientific and Industrial Research (CSIR)'s Meraka Institute, South Africa. The findings showed that there are no significantly observed differences between learning styles and gender in the ICT sector. The minimal differences in learning styles that were observed among male and female ICT employees had no significant effect on their career choices. Kempen and Kruger (2019) recently reported in their study on learning styles of optometry students at South Africa's University of the Free State using Kolb's LSI that first-, second- and fourth-year students identified the converging and assimilating learning styles as their two preferred learning styles. The third-year students showed the highest preference for the converger learning style, followed by the accommodator learning style. The study found no significant relationships among learning styles, gender, age, ethnicity and academic year. The finding on first-year students contradicts that of another study conducted by Vawda in 2005 at the Nelson Mandela Metropolitan University's Faculty of Health Sciences, which showed diverger learning style as the most predominant learning style of nursing students, followed by the accommodator learning style and assimilator learning style (Vawda 2005).

Although a study by Cabi and Yalcinalp (2012) found that assimilating learning style was the most preferred learning style of university students, neither gender nor learning strategies had any statistically significant effect on learning styles. Lee, Yeung and Ip (2016) explored the relationship between learning styles and the use of computer technology for language learning in a university setting. No significant learning style differences were found among university students and neither gender nor age had any impact on university students' use of computer technology. In another study that investigated the relationship between learning styles and critical thinking of undergraduate students in Iran, a statistically significant relationship was revealed among learning styles and age, gender, employment and semester of studying (Ghazivakili et al. 2014).

Nationality and high school attended by learners before enrolling in institutions of higher learning are other demographic variables that education literature links to learning styles. Marriott (2002) used Kolb's LSI to survey the learning style preferences of 410 undergraduate accounting students at two universities in the United Kingdom. The findings showed that students' learning style preferences were comprehensively diverse across nationalities, but no significant differences were observed. However, accommodation was the most preferred learning style amongst student nationality groups. Budeva, Kehaiova and Petkus (2015) compared learning style preferences of marketing students from the United States of America and Bulgaria by means of Kolb's LSI. Significant differences were observed as to how the students of these two countries (nationalities) preferred to learn. Bulgarian marketing students identified the converger learning style as their highest learning preference and diverger learning 
style as their lowest learning inclination. The predominant learning style among American marketing students was assimilation and accommodation displayed the lowest learning preference. In contrast to the above-mentioned findings (Marriott 2002; Budeva et al. 2015), a study by Adenuga (1989) that examined adult learners' readiness for self-directed learning and learning style preferences at Iowa University reported that learning style preferences and nationality groups did not differ significantly.

Nair and Lee (2016) explored the learning styles of undergraduate nursing students in India. Their findings indicate that the association between learning styles and high schools attended by students was not statistically significant. Given South Africa's effort to promote quality education and ensure students' readiness and better performance at universities, one would expect to find many studies investigating the relationship between high schools attended by students and their learning styles. Surprisingly, this study appears to be the first to examine such relationship in a university context in South Africa.

Students that are able to enrol in South African universities have either attended public high schools or private high schools. Both public and private (independent) schools are legislated by the South African Schools Act (1996). The South African government owns, controls, funds and manages public schools through provincial departments of education (South African Schools Act 1996). The funding model of public schools follows the quintile (1-5) approach in the allocation of financial resources to promote education inclusiveness or opportunities and alleviate poverty in previously disadvantaged communities. The wellresourced schools are in the quintile 5 category, while the poorly resourced schools are placed in the quintile 1 category. Learners enrolled in quintile 1,2 and 3 school categories are exempted from paying school fees, while those who enrol in quintiles 4 and 5 school categories pay school fees. Emphasising high polarisation of South Africa's secondary education system, Murray (2016) points out that the majority of black African students, representing 80 per cent of the total school population, come from mostly under-resourced rural or township high schools, while most of their white and Indian counterparts are able to attend well-resourced private schools. Unlike public schools, private schools are owned by secular or faith-based organisations and are governed and managed by boards. They are fee-paying and comply with education legislation. Although Tshwane University of Technology enrols matriculants coming from both public and private schools, most of its student population come from under-resourced schools.

\section{METHODOLOGY}

This cross-sectional survey assessed learning styles of logistics students at a South African 
institution of higher learning by means of the Kolb LSI. The target population consisted of 2 432 registered undergraduate logistics students in the Department of Marketing, Logistics and Sport Management at Tshwane University of Technology. A total of 790 registered logistics students were sampled randomly, based on their willingness and consent to participate in the study. The sample included first-, second-, third-year students, B.Tech. (fourth-year) students as well as students enrolled for the extended programme.

An adaptation of Kolb's LSI questionnaire (version 3.1) served to collect data from undergraduate logistics students. A self-administered LSI questionnaire was distributed to the students during scheduled classes. The questionnaire comprised two parts. The first part consisted of demographic and academic questions on aspects such as age, gender, nationality (South Africans vs. non-South Africans) and type of high school attended (public vs. private). These questions were included in the original Kolb LSI to assist in determining whether demographic and academic factors (variables) influence learning styles of undergraduate logistics students. The second part comprised the adapted Kolb LSI version 3.1 with 12 short statements, where registered undergraduate logistics students (respondents) were asked to rank their relative choice preference among the learning mode preferences. The scores resulting from the ranking of these students were used to classify each student into one of the four learning modes. The overall score of undergraduate logistics students was computed by adding the rankings of the four modes (CE, AC, RO and $\mathrm{AE})$. The student's higher scores on a specific learning mode indicate his/her greater emphasis on that learning mode. To determine whether the student showed comfortableness with $\mathrm{AC}$ over $\mathrm{CE}$ and $\mathrm{AC}$ over RO, two compounded scores deriving from the difference between $\mathrm{CE}$ and $\mathrm{AC}$, and $\mathrm{RO}$ and $\mathrm{AE}$ were used. A positive compounded score denotes that the student is more comfortable in dealing with abstractness and action, while a higher negative score indicates that the student emphasises concreteness and reflectiveness.

The LSI 3.1 questionnaire has been shown to successfully comply with reliability and validity test requirements (Kolb and Kolb 2005; D’Amore, James and Mitchell 2012). The LSI 3.1 questionnaire's Cronbach's alpha reliability values were found to range from 0.77 to 0.84 (Kolb and Kolb 2005; D'Amore et al. 2012), and from 0.75 to 0.81 (Li and Amstrong 2015). These exceeded the recommended threshold of 0.70 (Nunnally 1978). Both factor analysis and correlation analysis have proven the LSI to be a valid research instrument (Kolb and Kolb 2005).

Prior to the administration of questionnaires, ethical clearance was obtained from the Tshwane University of Technology's Research Ethics Committee and a written permission letter to administer the survey during classes was granted by the Head of the Department of 
Marketing, Logistics and Sport Management. Students were informed about many ethical aspects, including the aim of the study; what was required to do in the study; their rights as participants in the study; potential benefits that may derive from the study; and confidentiality and anonymity of respondents; no financial incentives or academic advantage or course credits to be offered when consenting to participate in the study. The anonymous self-assessment questionnaire was administered and collected by the researcher during scheduled classes in August 2017. Free and voluntary student participation was ensured by distributing questionnaires to undergraduate logistics students, then leaving the lecturing venues and instructing class representatives to inform him when to collect the completed questionnaires in the lecturing venues.

Collected data were analysed using the Statistical Package for Social Science (SPSS) version 23, where descriptive statistics and inferential statistics were performed. The descriptive statistics included frequencies, while inferential statistics was carried out through chi-square analysis to determine whether there was any association between the four learning styles and demographic factors (age, gender, type of school attended and nationality) $(p<0.05)$, as this study involves categorical variables. Respondents displaying multiple dominant learning styles were omitted from the analyses.

\section{RESULTS}

This survey study had a response rate of 32 per cent (790 of 2432 logistics students). Out of 790 questionnaires that were administered and returned, 361 questionnaires were excluded for being either incomplete or incorrectly filled out, resulting in 429 compliant questionnaires (18\% of the undergraduate logistics student population). Table 1 summarises the demographic factors of the respondents.

Table 1: Demographic factors of the respondents

\begin{tabular}{|l|l|c|c|}
\hline \multicolumn{1}{|c|}{ Variables } & \multicolumn{1}{|c|}{ Categories } & Frequencies & Percentages \\
\hline Gender & Male & 192 & 44.76 \\
\hline & Female & 237 & 55.24 \\
\hline Age Group (yrs) & $18-20$ years & 108 & 25.2 \\
\hline & $21-23$ years & 251 & 58.5 \\
\hline & 24 years and over & 70 & 16.4 \\
\hline Nationality & South Africans & 416 & 96.96 \\
\hline & Foreigners & 13 & 3.04 \\
\hline High School Attended & Public & 356 & 82.98 \\
\hline & Private & 73 & 17.02 \\
\hline
\end{tabular}


The findings of the dominant learning style of undergraduate logistics students at a South African institution of higher learning using Kolb's LSI, showed that the most dominant learning style amongst the respondents (undergraduate logistics students) was the accommodating learning style $(n=167,38.9 \%)$, followed by assimilating $(n=128,29.8 \%)$ and diverging $(n=57$, $13.3 \%$ ). The least dominant learning style was the converging style $(n=40,9.3 \%)$ (Figure 1). More than one dominant learning style was indicated for $8.6 \%(n=37)$ of the sample. The majority of respondents who exhibited multiple learning styles had two dominant learning styles. Moreover, 2 respondents were found to have 3 dominant learning styles.

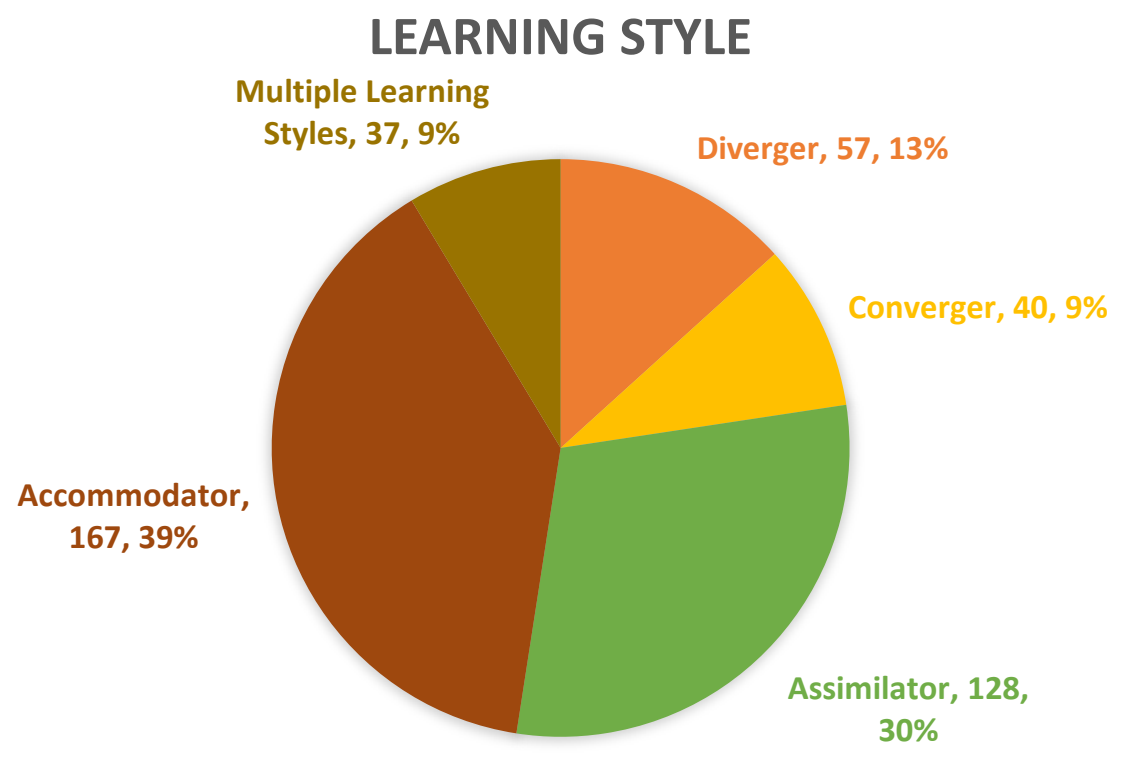

Figure 1: Dominant learning styles of respondents

To explore the relationships between learning styles and demographic factors, Chi-square test results are summarised in Tables 2 and 3. Table 2 shows that there was a significant relationship between learning style and gender $\left(X^{2}(3)=15.242, p<.005\right)$. However, no significant relationships were found between learning style and age or learning style and the type of high school attended (public or private).

Table 2: Chi-square Test

\begin{tabular}{|l|c|c|c|}
\hline \multicolumn{1}{|c|}{ Variables } & Value & df & Asymptotic significance (2-sided) \\
\hline Gender & 15.242 & 3 & .002 \\
\hline Age & 3.167 & 6 & .788 \\
\hline Type of School Attended & 5.329 & 3 & .149 \\
\hline
\end{tabular}


The expected count within the cells did not meet the minimum requirement, violating an assumption for the Chi-square test to compute the association between learning styles and nationality. Therefore, the Fisher-Freeman-Halton Exact Test for contingency tables was used for this analysis. The results of Fisher's Exact Test, as depicted in Table 3, indicated that learning styles and nationality were not significantly associated.

Table 3: Fisher's Exact Test

\begin{tabular}{|l|c|c|}
\hline Variable & Value & Exact Sig. (2-sided) \\
\hline Nationality & 3.135 & .796 \\
\hline
\end{tabular}

Table 4 shows that among male logistics students, the most dominant learning style was diverging (66.67\%), followed by assimilating (44.53\%) and the convergence style was found to be the least dominant (37.50\%). Conversely, converging learning was found to be the most dominant among female logistics students $(62.50 \%)$, followed by the accommodating learning style, while the diverging learning style (33.33\%) was found to be the least dominant.

Table 4: Learning style and gender cross tabulation

\begin{tabular}{|l|c|c|c|}
\hline \multirow{2}{*}{ Learning Style } & \multicolumn{2}{c|}{ Gender } & \multirow{2}{*}{ Total } \\
\cline { 2 - 3 } & Male & Female & \\
\hline Diverging (\%) & $38(66.67)$ & $19(33.33)$ & $57(14.54)$ \\
\hline Converging (\%) & $15(37.50)$ & $25(62.50)$ & $40(10.20)$ \\
\hline Assimilating (\%) & $57(44.53)$ & $71(55.47)$ & $128(32.65)$ \\
\hline Accommodating (\%) & $63(37.72)$ & $104(62.28)$ & $167(42.60)$ \\
\hline Total & 173 & 219 & 392 \\
\hline
\end{tabular}

$\mathrm{N}=392$

\section{DISCUSSION OF THE RESULTS}

This study sought to identify the dominant learning styles of undergraduate logistics students at a South African institution of higher learning and to explore the relationships between learning styles and demographic factors, including gender, age group, type of high school attended and nationality. Despite changing demographic profiles in institutions of higher learning globally, studies assessing the relationships between learning styles and demographic factors remain scant (D'Amore et al. 2012). Furthermore, logistics students appear to be one of the least studied groups with respect to learning styles and Kolb's LSI is the least used data collection tool (instrument) in logistics as compared to other disciplines such as nursing, education and marketing sciences. Such lack of instrument usage makes it difficult for this study's findings to be related to previous ones in the same discipline. Therefore, the findings of 
this study are compared to those of other disciplines.

Although the current study's findings display diversity in learning styles among undergraduate logistics students, accommodators were the most dominant for the sampled population. This means that these students emphasise CE and AE learning modes in their learning process. Given that logistics falls under business studies, this finding concurs with a study by Kolb (2015) that examined the relationship between students' learning styles and undergraduate college major (early training specialisation in college). His findings reveal that undergraduate business majors exhibited accommodator learning styles. In addition, this finding is consistent with several studies in nursing sciences (Gyeong and Myung 2008; Hauer, Straub and Wolf 2005; Smith 2010). In this respect, active engagement of students toward learning seems critical in enhancing learning opportunity grabbing (task-oriented skills) and creation of hands-on experience. This has teaching implications, suggesting that logistics lecturers need to find ways that enhance students' learning engagement and adaptation to new learning tools (e.g. online learning and simulation of logistics concepts) in order to create the hands-on experience required by the industry.

Conversely, previous studies in other disciplines, including nursing sciences (D'Amore et al. 2012), education sciences (Magdalena 2015), cognitive sciences (Sam and Ling 2000) and business sciences (Budeva et al. 2015; Ghaffari et al. 2013; Goorha and Mohan 2009) have found that accommodation was the least displayed learning style. In these studies, undergraduate students were found to emphasise either the converging learning style or assimilating learning style.

The current study also showed that assimilation followed accommodation, meaning these two are the dominant learning styles in the sampled population. Kolb $(1984 ; 1999 ; 2015)$ describes the accommodating learning style as one that emphasises acting competences as an individual actively engages in the learning process and encounters challenges leading to the creation of hands-on experience. Accommodators often prefer working in groups and operating in practical fields such as education and business and in "action-oriented" professions such as marketing, teaching and nursing. The same author also describes the assimilating learning style as one that emphasises thinking competences, involving "organising information, building conceptual models, testing theories and ideas, designing experiments, and analysing quantitative data" (Kolb 2015, 134). Such learning style is more appropriate for individuals with basic sciences and mathematical competences, leading to careers that involve research and planning (Kolb 1984; 1999). In addition, accommodators have been described as individuals who display extraverted sensation and perception learning type and assimilators as individuals who exhibit the introverted intuitive learning type (Kolb 1984). Therefore, the majority of 
undergraduate logistics students $(68.7 \%)$ are a mixture of individuals with acting skills and extraverted personality type, on the one hand, and thinking skills and introverted personality type on the other hand. This requires logistics lecturers (educators) to concentrate on nurturing students with accommodating and assimilating learning preferences through alignment or adaptation in teaching instructions and strategies.

Since learning styles or preferences are believed to be flexible and changing during the human learning journey, due to previous experiences and habits as well as specific environmental requirements from professional choice and the associated tasks (Kolb 2015), logistics lecturers (educators) also need to cater for the learning styles of logistics students displaying diverging and converging learning styles and those displaying multiple learning styles. This is paramount as the learning styles of logistics students may change from one learning style to another as these students progress in their academic journey at institutions of higher learning in the country. Effective accommodation of different learning styles can be ensured by using a variety of instructional methods or a multimodal teaching approach to learning in classroom.

Given that the demographic profile of students changes over time in institutions of higher learning and across disciplines, it becomes important to evaluate the relationships between learning styles and demographic factors among students in general and undergraduate logistics students in particular, since studies assessing such groups of students using Kolb's LSI are quasi-inexistent globally and in South Africa. This study found that learning styles and gender of undergraduate logistics students are significantly related. This finding is in agreement with prior studies in nursing sciences (D’Amore et al. 2012), and in health sciences (Zoghi, Brown, Williams, Roller, Jaberdeh, Palermo, McKenna, Wright, Baird, Schneider-Kolsky, Hewitt, Sim and Holt 2010).

When cross tabulating gender and learning styles, gender differences in learning styles were found. The results highlight that among male logistics students, diverging learning style was the most dominant (66.67\%) and converging learning style was the least dominant $(37.50 \%)$. On the other hand, converging learning style was the most dominant among female logistics students (62.50\%) and diverging learning style was the least dominant (33.33\%). This means that the majority of male logistics students are divergers (emphasising CE and RO), while the majority of their female counterparts are convergers (emphasising AC and AE). More interestingly, these results reveal the exact opposite picture of what the learning style of the entire population show, whereby accommodating and assimilating learning styles were dominant. This has implications for practice, suggesting that logistics lecturers need to find a variety of instructional strategies that promote effective learning considering gender 
differences. Because of these gender differences in learning styles, logistics lecturers should also balance instructional strategies to cater for other least predominant learning styles through adaptation. By doing so, students of a variety of learning styles (divergers, convergers, accommodators and assimilators) are all accommodated in classroom.

No statistically significant associations were revealed among learning styles and age group, and learning styles and the type of high school attended. These findings are similar to those of Nair and Lee (2016) that showed that learning styles are not related to both age group and high schools attended. However, the finding pertaining to the association between learning styles and age groups contradicts previous studies by Kolb (1976) and Dorsey and Pierson (1984), who found differences between learning styles and age group. Very limited studies assessed the statistical association between learning styles and type of high school attended by students. This makes it difficult to relate the current study to previous findings, except those by Nair and Lee (2016).

The current study's findings observed no statistically significant differences in learning styles of logistics students based on nationality. This is consistent with the study of Adenuga (1989) that found that learning style preferences did not differ based on nationality groups. The study indicated that nationality was the predictor of the "level of readiness for self-directed learning than learning styles" (Adenuga 1989, 144). This finding and conclusion was unexpected as foreign undergraduate students pursuing logistics qualifications were anticipated to display differing learning styles due to cultural learning differences and previously exposed differences in teaching styles at high schools, as compared to their South African counterparts.

\section{CONCLUSION}

This study focused on assessing the learning styles of undergraduate logistics students at a South African institution of higher learning. It highlights the need for logistics lecturing staff to be aware of diversity in students' learning styles, which necessitates teaching strategy adaptation and matching to promote student learning engagement in classroom and academic performance (success) driven by industry needs. The current study highlights that the majority of undergraduate logistics students display the accommodator-learning style, which is characterised by a combination of $\mathrm{CE}$ and $\mathrm{AE}$. This shows that most undergraduate logistics students prefer to learn through acting to create hands-on experience. As implication for practice, the current study suggests that logistics lecturers (educators) need to identify avenues that promote and enhance active student engagement in classrooms and adaptation to new learning systems or tools (e.g. online learning, simulated logistics/supply chain process gaming and discussion groups) that shape students' hands-on experiences, critical thinking and 
problem-solving skills, which are sought-after competences or requirements of the industry.

The study also highlights that accommodators were followed by assimilators. The combined proportion of students displaying both accommodating and assimilating learning styles represent more than two-thirds of the sampled population (68.7\%). This combination of students with acting skills and extraverted personality type and thinking skills and introverted personality type requires logistics lecturers (educators) to adapt and nurture students with these predominantly learning styles (accommodators and assimilators), while catering for those with diverging and converging learning styles and those displaying multiple learning styles. Such concerted and adapted effort requires the use of various instructional approaches or teaching strategies to learning.

This study's findings showed that learning styles and gender of undergraduate logistics students were significantly related. Gender differences are such that the majority of male logistics students are divergers, while female students are convergers. These results contradict those of the entire population, showing that accommodators and assimilators as the dominant learning styles. In addition, the findings revealed no statistically significant relationships among learning styles and age group, learning styles and the type of school attended, and learning styles and nationality. Since this study is the first examining learning styles of logistics students using Kolb's LSI, this study's findings need to be confirmed by conducting further empirical studies using bigger sample sizes in other institutions of higher learning offering logistics qualifications at undergraduate level.

\section{REFERENCES}

Adenuga, B. O. 1989. Self-directed readiness and learning style preferences of adult learners. PhD thesis. Department of Professional Studies in Education. Iowa State University.

Akkoyunlu, B. and M. Y. Soylu. 2008. A study of student's perceptions in a blended learning environment based on different learning styles. Educational Technology \& Society 11(1): 183193.

Bosman, A. and S. Schulze. 2018. Learning style preferences and Mathematics achievement of secondary school learners. South African Journal of Education 38(1): 1-8.

Boström, L. 2012. Do ten-year-old children in Sweden know how they learn? A study of how students believe they learn compared to their learning style preferences. International Education Studies 5(6): 11-23.

Budeva, D., M. Kehaiova and E. Petkus. 2015. Nationality as a determinant of learning styles: Comparing marketing students from Bulgaria and the USA. e-Journal of Business Education \& Scholarship of Teaching 9(1): 97-106.

Cabi, E. and S. Yalcinalp. 2012. Lifelong learning considerations: Relationship between learning styles and learning strategies in higher education. Procedia - Social and Behavioral Sciences 46: 44574462.

Carol, C. 2015. Learning styles in higher education. A case study in history training. The $6^{\text {th }}$ International Conference Edu World 2014 "Education Facing Contemporary World Issues", 7th - 9th 
November 2014. Procedia - Social and Behavioral Sciences 180: 256-261.

Cho, S. 2016. Exploring learning and teaching styles of mathematics at an urban university in South Africa. Ph.D. thesis. Department of Mathematics, Science and Technology. University of Johannesburg.

D'Amore, A., S. James and E. K. L. Mitchell. 2012. Learning styles of first-year undergraduate nursing and midwifery students: A cross-sectional survey utilising the Kolb Learning Style Inventory. Nurse Education Today 32: 506-515.

Dlodlo, N., P. S. Mvelase and C. Krause. 2010. A gender-based survey of learning styles of South African employees in ICT careers, 1-15.

Dorsey, O. L. and M. J. Pierson. 1984. A descriptive study of adult learning styles in a non-traditional education program. Lifelong Learning 7: 8-11.

Dunn, R. and K. Dunn. 1978. Teaching students through their individual learning styles: A practical approach. Reston, VA: Reston Publishing.

Felder, R. M. 1996. Matters of style. ASEE Prism 6(4): 18-23.

Felder, R. M and B. A. Solomon. 1997. Index of learning styles. http://www.ncsu.edu/felderpublic/ILSpage.html (Accessed 12 November 2017).

Fleming, N. D. 2001. Teaching and learning styles: VARK Strategies. Honolulu Community College.

Fletcher, S., J. Potts and R. Ballinger. 2008.The pedagogy of integrated coastal management. The Geographical Journal 174(4): 374-386.

Gardner, B. S. and S. J. Korth. 1998. A framework for learning to work in teams. Journal of Education for Business 74(1): 28-33.

Garrison, D. R. and H. Kanuka. 2004. Blended learning: Uncovering its transformative potential in higher education. The Internet and Higher Education 7(2): 95-105.

Ghazivakili, Z., R. N. Nia, F. Panahi, M. Karimi, H. Gholsorkhi and Z. Ahmadi. 2014. The role of critical thinking skills and learning styles of university students in their academic performance. Journal of Advances in Medical Education and Professionalism 2(3): 95-102.

Ghaffari, R., F. S. Ranjbarzadeh, E. F. Azar, S. Hassanzadeh, N. Safaei, P. Golanbar, H. Mazouchian and E. Abbasi. 2013. The analysis of learning styles and their relationship to academic achievement in medical students of basic sciences program. Research and Development in Medical Education 2(2): 73-76.

Goorha, P. and V. Mohan. 2009. Understanding learning preferences in the business school curriculum. Journal of Education for Business 85(3): 145-152.

Graham, C. R. 2006. Blended learning systems: Definition, current trends and future directions. In Handbook of blended learning: Global perspectives, local designs, ed. C. J. Bonk and C. R. Graham. San Francisco, CA: Pfeiffer.

Gyeong, J. A. and S. Y. Myung. 2008. Critical thinking and learning styles of nursing students at the baccalaureate-nursing program in Korea. Contemporary Nurse 29(1): 100-109.

Hauer, P., C. Straub and S. Wolf. 2005. Learning styles of allied health students using Kolb's LSI-IIa. Journal of Allied Health 34(3): 177-182.

Herrmann, N. 1989. The creative brain. Lake Lure, NC: Brain Books.

Holley, J. H. and E. K. Jenkins. 1993. The relationship between learning style and performance on various test question formats. Journal of Education for Business 68: 301-308.

Honey, P. and A. Mumford. 1982. The manual of learning styles. Maidenhead, UK: Peter Honey.

Jorgensen, G. W. 2006. One size doesn't fit all: Achieving accountability through application of learning patterns. In Learning styles and learning a key to meeting the accountability demands in education, ed. R. R. Sims and S. J. Sims. New York: Nova Science.

Kaur, M. 2014. Comparative analysis of learning styles of secondary school students by gender and grade. Journal of Advance Research in Education, Technology \& Management 2(3): 212-215. 
Keefe, J. W. 1979. School applications of the learning style concept: Student learning styles. Reston, VA: National Association of Secondary School Principals.

Kempen, E. and S. B. Kruger. 2019. Kolb's learning styles of optometry students at the University of the Free State. South Africa. African Vision and Eye Health 78(1): a454.

Kiwanuka, H. N., J. Van Damme, W. Van den Noortgate, D. N. Anumendem and S. Namusisi. 2015. Factors affecting Mathematics achievement of first-year secondary school students in Central Uganda. South African Journal of Education 35(3): Art. \# 1106, 16 pages.

Kolb, D. A 1976. Learning style inventory: Technical manual. Boston, MA: McBer.

Kolb, D. A. 1984. Experiential learning: Experience as the source of learning and development. Englewood Cliffs, NJ: Prentice-Hall.

Kolb, D. A. 1985. Learning-style inventory: Self-scoring inventory and interpretation booklet. Boston: McBer.

Kolb, D. A. 1999. The Kolb learning-style inventory. Version 3. Boston: Hay Resources Direct.

Kolb, A. Y. and D. A. Kolb. 2005. The Kolb learning style inventory. Version 3.1: 2005 technical specifications. Philadelphia: Hay Group, Experience Based Learning Systems, Inc.

Kolb, D. A. 2015. Experiential learning: Experience as the source of learning and development. $2^{\text {nd }}$ Edition. Upper Saddle River, New York: Pearson Education, Inc.

Lee, C., A. S. Yeung and T. Ip. 2016. Use of computer technology for English language learning: Do learning styles, gender, and age matter? Computer Assisted Language Learning 29(5): 1035-1051.

Li, M. and S. J. Armstrong. 2015. The relationship between Kolb's experiential learning styles and Big Five personality traits in international managers. Personality and Individual Differences 86: 422426.

Litzinger, M. E. and B. Osif. 1993. Accommodating diverse learning styles: Designing instruction for electronic information sources. In What is good instruction now? Library instruction for the $90 \mathrm{~s}$, ed. L. Shirato. Ann Arbor, MI: Pierian Press.

Lovelace, M. K. 2005. Meta-analysis of experimental research based on the Dunn and Dunn model. The Journal of Educational Research 98(3): 176-183.

Macdonald, J. 2008. Blended learning and online tutoring. ${ }^{\text {nd }}$ Edition. Hampshire, UK: Gower.

Magdalena, S. M. 2015. The relationship of learning styles, learning behaviour and learning outcomes at the Romanian students. The 6th International Conference Edu World 2014 "Education Facing Contemporary World Issues", 7th - 9th November 2014. Procedia - Social and Behavioral Sciences 180: 1667-1672.

Marriott, P. 2002. A longitudinal study of undergraduate accounting students' learning style preferences at two UK universities. Accounting Education 11(1): 43-62.

Mills, D. W. 2002. Applying what we know student-learning styles. Retrieved April 7:2009.

Murray, M. 2016. Does poor quality schooling and/or teacher quality hurt black South African students enrolling for a degree at the University of KwaZulu-Natal? PLOS ONE 11(4): e015309.

Murphy, R. J., S. A. Gray, S. R. Straja and M. C. Bogert. 2004. Student learning preferences and teaching implications. Journal of Dental Education 68: 859-866.

Nair, M. A. and P. Lee. 2016. An exploration of the learning style among undergraduate nursing students from an Indian perspective. Journal of Nursing and Health Science 5(5): 1-4.

Nunnally, J. 1978. Psychometric theory. New York: McGraw-Hill.

Pashler, H., H. McDaniel, D. Rohrer and R. Bjork. 2008. Learning styles: Concepts and evidence. Psychological Science in the Public Interest 9(3): 103-119.

SA see South Africa.

Sam, H. K. and C. K. Ling. 2000. Effects of learning styles on undergraduates' attitudes, navigational patterns, and use of navigational tools in hypermedia-based learning. The Electronic Journal of 
Information Systems in Developing Countries 2(3): 1-11.

Shah, K., J. Ahmed, N. Shenoy and N. Srikant. 2013. How different are students and their learning styles? International Journal of Research in Medical Sciences 1(3): 101-104.

Shanker, A. 1990. The end of the traditional model of schooling - and a proposal for using incentives to restructure our public schools. Phi Delta Kappan January: 345-357.

Slater, J. A., H. L. Lujan and S. E. DiCarlo. 2007. Does gender influence learning style preferences of first-year medical students? Advances in Physiology Education 31: 336-342.

Smith, P. L. and T. J. Ragan. 1999. Instructional design. New York: Macmillan Publishing Company.

Smith, A. 2010. Learning styles of registered nurses enrolled in an online nursing program. Journal of Professional Nursing 26(1): 49-53.

South Africa. 2014. Department of Higher Education and Training. Call for comments on the national scarce skills list: Top 100 occupations in demand. Government Gazette 380, May 23. (Government notice No. 37678). http://www.saqa.org.za/docs/news/2014/Scarce\%20skills\%20list\%20gazette \%20call \%20for\%20comments\%202014.pdf (Accessed 12 June 2016).

South African Schools Act. 1996 (Act No 84 of 1996).

Sun, K. T., Y. C. Lin and C. J. Yu. 2008. A study on learning effect among different learning styles in a Web-based lab of science for elementary school students. Computers \& Education 50(4): 14111422.

Terrell, S. 2002. Learning style as a predictor of success in a limited residency doctoral program. The Internet in Higher Education 5(4): 345-352.

Vawda, A. 2005. The learning styles of first year university students. Magister Artium dissertation. Faculty of Health Sciences. Nelson Mandela Metropolitan University.

Vishwakarma, P., O. P. Verma and M. Mitra. 2015. Learning styles in relation to intelligence, locale and sex. International Journal of Education \& Management Studies 5(2): 148-151.

Vita, G. D. 2001. Learning styles, culture and inclusive instruction in the multicultural classroom: A business and management perspective. Innovations in Education and Teaching International 38(2): $165-174$.

Voos, R. 2003. Blended learning what is it and where might it take us? Sloan-C View 2(1): 2-5.

Wehrwein, E. A., H. L. Lujan and S. E. DiCarlo. 2007. Gender differences in learning style preferences among undergraduate physiology students. Advances in Physiology Education 31: 153-157.

Zoghi, M., T. Brown, B. Williams, L. Roller, S. Jaberzadeh, C. Palermo, L. McKenna, C. Wright, M. Baird, M. Schneider-Kolsky, L. Hewitt, J. Sim and T.-A. Holt. 2010. Learning style preferences of Australian health science students. Journal of Allied Health 39(2): 95-103. 